\title{
Maintaining Relationships With Supply Chain Partners: A Case Study
}

Charles J. Quigley, Jr., Bryant University, USA

Frank G. Bingham, Jr., Bryant University, USA

\begin{abstract}
This case study describes efforts of a market leader in the communication infrastructure industry to assess the relationships they have developed with their global supply chain partners. Changes in the industry have resulted in geographic shifts of existing and potential supply chain suppliers and customers. In an effort to determine if commitment to customer service has resulted in increased customer satisfaction and loyalty, research was conducted to assess their performance. The results of this research were compared to previous research to determine if their service program has successfully differentiated them from their competitors.
\end{abstract}

Keywords: survey research, performance measurement, procurement/purchasing processes, supplier policies and procedures, case study, factor analysis.

\section{INTRODUCTION}

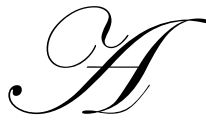

n emerging concern associated with outsourcing is the ability to effectively manage complex global supplier relationships (Sanders, et al., 2007). Complicating an organization's ability to effectively manage their supply chain are complications of global sourcing. A product may be designed in one country, manufactured in another, and parts/components sourced in yet another (Van Pham, 2006). Increasingly, U.S. firms are turning to suppliers of products and services located in low-cost countries (LCC) that offer an attractive alternative to the higher cost suppliers from more developed economies (Rumsock, Russell, and Thomchick, 2007). However, evidence indicates there is much diversity in sourcing and supply chain performance among differing LCC regions and nations. This complicates the task of effectively managing buyer-seller relationships.

To maintain and improve a firm's future competitive advantage in global competition, it must develop and enhance management knowledge of differing regions and nations of supply to optimize strategic value (Rumsock, Russell, and Thomchick, 2007). As part of the supplier relationship management process, there is a need to develop more advanced working relationships or alliances (Knemeyer, Corsi and Murphy, 2003; Moberg and Speh, 2003; Lambert, Knemeyer, and Gardner, 2004). This involves a commitment over an extended time period to work together for the mutual benefit of all parties, sharing relevant information along with the risks and rewards of the relationship (Engle, 2007).

There are a number of factors that have been hypothesized to influence the relative importance of price in supply chain relationships. Among these factors is the stage of the product(s) in the life cycle, nationality of the organization(s), and competitive intensity within the industry. A product, early in its life cycle is perceived by existing and potential customers to be differentiated from competitive offerings. As demand within the market grows, the challenge for the supplying firm is to gear up supply to meet these demands. The seller controls price and the customer becomes a price-taker. As the product matures, it loses the perception of being differentiated and evolves into commodity status. Price control shifts, the customer now uses price to play one supplier off against another and the supplier becomes the price-taker. To counter the growing power of the buyer, the seller attempts to differentiate their offering by shifting focus from the product to other elements, including service. As the product moves through the life cycle, moving from unique to differentiated to commodity status, the nature of the relationship between buyers and sellers also shifts. 


\section{THE ISSUES}

Frank Corly, Senior Vice President of Sales and Marketing for COMMCO and the manager of the organization's largest strategic business unit (SBU) prepared for his meeting with Alan Land, Manager of Customer Services, Michael Bhada, Manager of Quality Assurance and Carol Brigman, Manager of Information Services, to discuss the results of a recently completed survey of their supply chain partners. Also attending this meeting would be David Brown, President of COMMCO and Valarie Montross, Vice President of Finance. Frank was reviewing the results of the survey that had been provided by a research firm hired to conduct the survey. This was the same firm the company used to conduct several past customer surveys.

Frank realized the results would be used to assess the success of the company's strategic initiatives to differentiate its offerings from those of the competitors. Although sales had increased over the last 12 month period from the prior 12 month period, profit margins had not moved. He was hoping to use the survey results to maintain the commitment of the CEO toward the customer service initiatives they had introduced over the past year.

COMMCO is a multinational manufacturer and marketer of an array of commercial products used in the communication industry. COMMCO has been in business for over 50 years, employing approximately 5000 people worldwide. They provide materials for commercial, industrial and military applications. The company offers contract manufacturing and product design services, and provides product coating, lamination, extrusion, printing, slitting and weaving at its ISO 9001:2000-certified plants. Corly believes that a major reason for their continuing success is the ability to develop and maintain long-term relationships with their customers. They also believe that their commitment to satisfying customers by providing quality products, supported by excellent service, is the cornerstone of their competitive advantage. However, over the last several years they have seen their profit margins erode, sales stagnate, and competitors grow more aggressive. Competitors from Europe and Asia have been able to match the quality of COMMCO's products and have undercut their prices. Responding to these competitive pressures, they embarked on an aggressive growth program to expand their customer base into Asian markets. They intended to leverage their self-perceived outstanding service to customers to recapture market leadership and justify their premium pricing.

\section{THE SURVEY}

Discussions were initially held to conceptualize the process for gathering information that would allow the firm to assess the results of its customer service initiatives. Frank included Alan Land, Carol Brigman, Mark Arrington, Controller of International Operations, and the regional sales managers for Europe and Asia in these discussions. While traditional financial benchmarks would be necessary, Frank argued that customer perceptions of COMMCO's performance and their competitor's performance would also be important. These measures would allow them to determine what COMMCO was doing well and also what they were not doing well.

They decided that a survey of their customers was the best way to get the information they required. Further discussion resulted in a consensus of opinion concerning the objectives of the survey. They decided the survey should:

- Identify the attributes, or criteria, customers use to evaluate their suppliers, including COMMCO

- $\quad$ Determine the relative importance customers attach to the criteria used to evaluate suppliers

- $\quad$ Assess the performance of COMMCO on these criteria

- $\quad$ Compare COMMCO's performance to that of its closest competitor(s).

\section{DEPTH INTERVIEWS}

Interviews with managers and field sales representatives focused on identifying key attributes that were believed to be instrumental in a customer's evaluation of their suppliers. The general question that was asked was: What attributes do customers use to evaluate the performance of key suppliers? Both managers and field sales representatives agreed on the set of attributes they believed were important. These attributes were grouped into seven areas: transaction fulfillment, complaint resolution, price, customer contact, availability/delivery/quality, technical 
support, and overall relationship. These attributes were similar to attributes that were indentified and included in previous customer surveys, which were undertaken every other year by the Customer Service Department.

\section{SURVEY INSTRUMENT}

Based on the results of the depth interviews, a survey instrument was developed. This instrument, which included measures (characteristics) of the responding firm, asked the respondent to assess the importance of criteria used to evaluate their suppliers. Respondents were then asked to evaluate the performance of COMMCO and the performance of the closest competitor (identified by the respondents). The survey was developed and tested to insure that the wording of questions was not confusing and that the scales used to measure responses were appropriate.

\section{SURVEY ADMINISTRATION}

The survey was mailed to individuals at customer organizations that were identified by field sales representatives. A letter from the Vice President of Sales and Marketing was included, which explained the purpose of the survey and assured the respondents of anonymity. Enclosed with the survey was a return envelope to be returned to the independent external research firm contracted to conduct the survey. An electronic copy of the survey was created and provided, as an option to the customer.

\section{SURVEY FINDINGS}

Table 1 in the Appendix describes the respondents to the current survey and three prior customer surveys conducted in 2002, 2004, and 2006. The response rate for the current survey was $11 \%$. The response rate for the electronic version is unknown; however the completion rate was $65 \%$. Response rates for prior studies were $16 \%$ in 2006, 34\% in 2004, and an estimated $8 \%$ in 2002.

\section{IMPORTANCE OF ATTRIBUTES}

The importance that customers attached to the criteria they used to evaluate existing suppliers is provided in Figure 1. This figure shows the mean scores of respondents in the current survey for each criterion. Table 2 in the Appendix provides the importance of criteria reported in prior studies.

\section{DIMENSIONS USED TO EVALUATE SUPPLIERS}

To determine if the seventeen criteria that respondents evaluated in terms of their importance in supplier selection represented a smaller number of underlying dimensions upon which suppliers are evaluated, the research firm performed a factor analysis. The results of this analysis are presented in Table 3. This table identifies the dimensions that account for most of the variation in evaluations among and between the respondents. The criteria for each dimension are listed by its relative importance. 
Figure 1: Importance of Evaluation Criteria

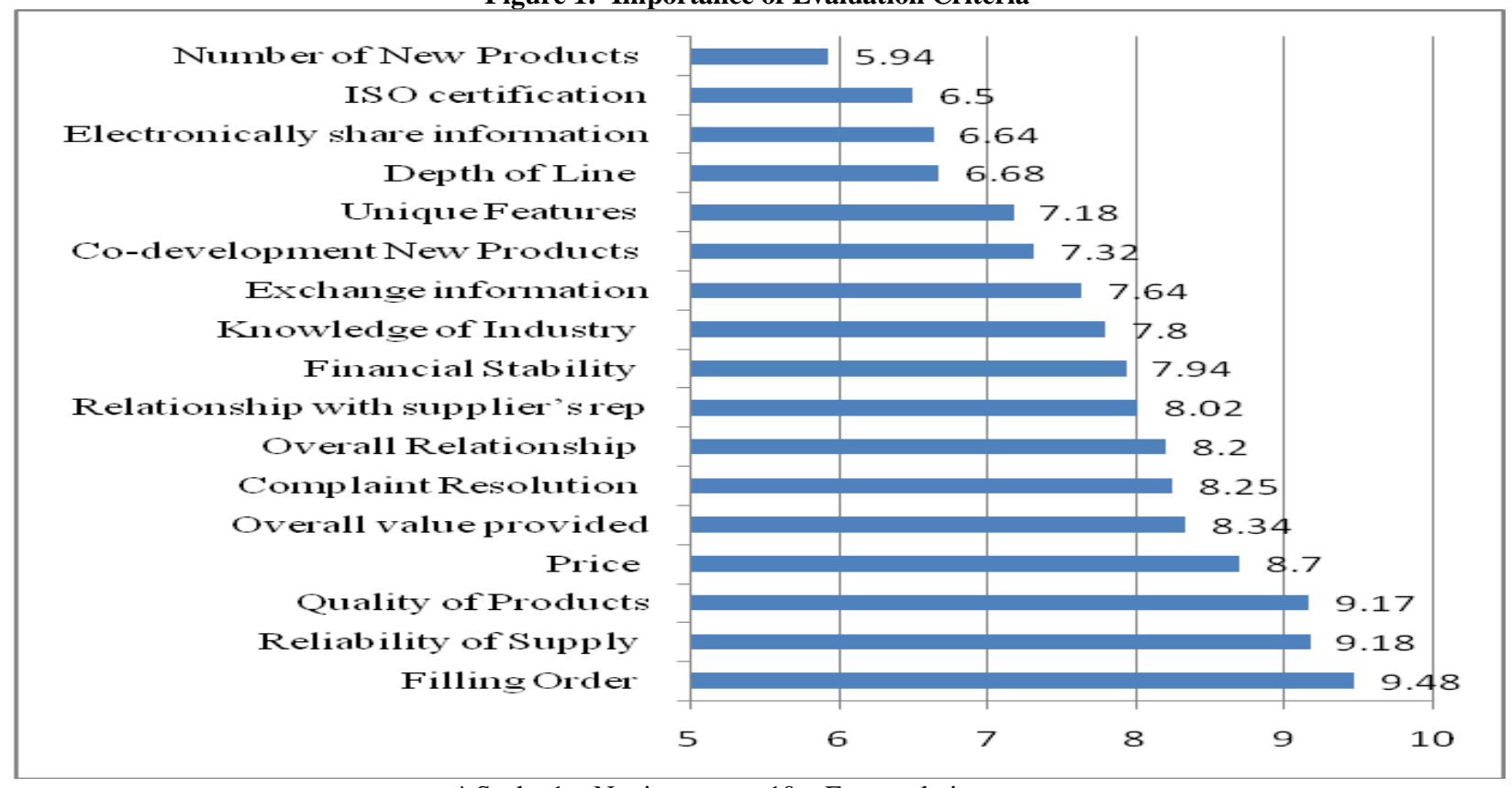

* Scale 1 - Not important, 10 - Extremely important

Table 3: Dimensions Customers Use to Evaluate Suppliers

\begin{tabular}{|c|c|c|c|c|c|}
\hline & $\begin{array}{c}\text { Dimension } 1 \\
(34 \%)^{1}\end{array}$ & $\begin{array}{c}\text { Dimension } 2 \\
(19 \%)^{1}\end{array}$ & $\begin{array}{c}\text { Dimension } 3 \\
(7 \%)^{1}\end{array}$ & $\begin{array}{c}\text { Dimension } 4 \\
(6 \%)^{1}\end{array}$ & $\begin{array}{c}\text { Dimension } 5 \\
(6 \%)^{1}\end{array}$ \\
\hline Criterion 1 & $\begin{array}{l}\text { Unique Product } \\
\text { Features }\end{array}$ & Order Fulfillment & $\begin{array}{l}\text { Financial Stability of } \\
\text { Supplier }\end{array}$ & $\begin{array}{l}\text { Relationship with } \\
\text { Representative of } \\
\text { Supplier }\end{array}$ & $\begin{array}{l}\text { Knowledge of } \\
\text { your Industry }\end{array}$ \\
\hline Criterion 2 & $\begin{array}{l}\text { Abundance of New } \\
\text { Products }\end{array}$ & $\begin{array}{l}\text { Reliability of } \\
\text { Supply }\end{array}$ & $\begin{array}{l}\text { Electronically Share } \\
\text { Info with Supplier }\end{array}$ & $\begin{array}{l}\text { Overall Relationship } \\
\text { with Supplier }\end{array}$ & \\
\hline Criterion 3 & $\begin{array}{l}\text { Depth of Product } \\
\text { Line }\end{array}$ & $\begin{array}{l}\text { Quality of } \\
\text { Supplier's } \\
\text { Products } \\
\end{array}$ & & & \\
\hline Criterion 4 & $\begin{array}{l}\text { Co-development of } \\
\text { New Products }\end{array}$ & & & & \\
\hline Description & $\begin{array}{l}\text { Supplier's Product } \\
\text { Offerings }\end{array}$ & $\begin{array}{l}\text { Excellence of } \\
\text { Supplier's } \\
\text { Service and } \\
\text { Offerings } \\
\end{array}$ & $\begin{array}{l}\text { Supplier's Strength } \\
\text { and Sophistication }\end{array}$ & $\begin{array}{l}\text { Relationship with } \\
\text { Supplier }\end{array}$ & $\begin{array}{l}\text { Knowledge } \\
\text { Supplier has of } \\
\text { Customer }\end{array}$ \\
\hline
\end{tabular}

1 - Percent of total variation accounted for/ Varimax Rotation

\section{COMMCO'S PERFORMANCE}

Customers were asked whether they agreed or disagreed with multiple statements concerning COMMCO's performance. Figure 2 presents the customers' mean assessment (agree or disagree) with these performance statements.

Figure 2: Performance Assessment of COMMCO 


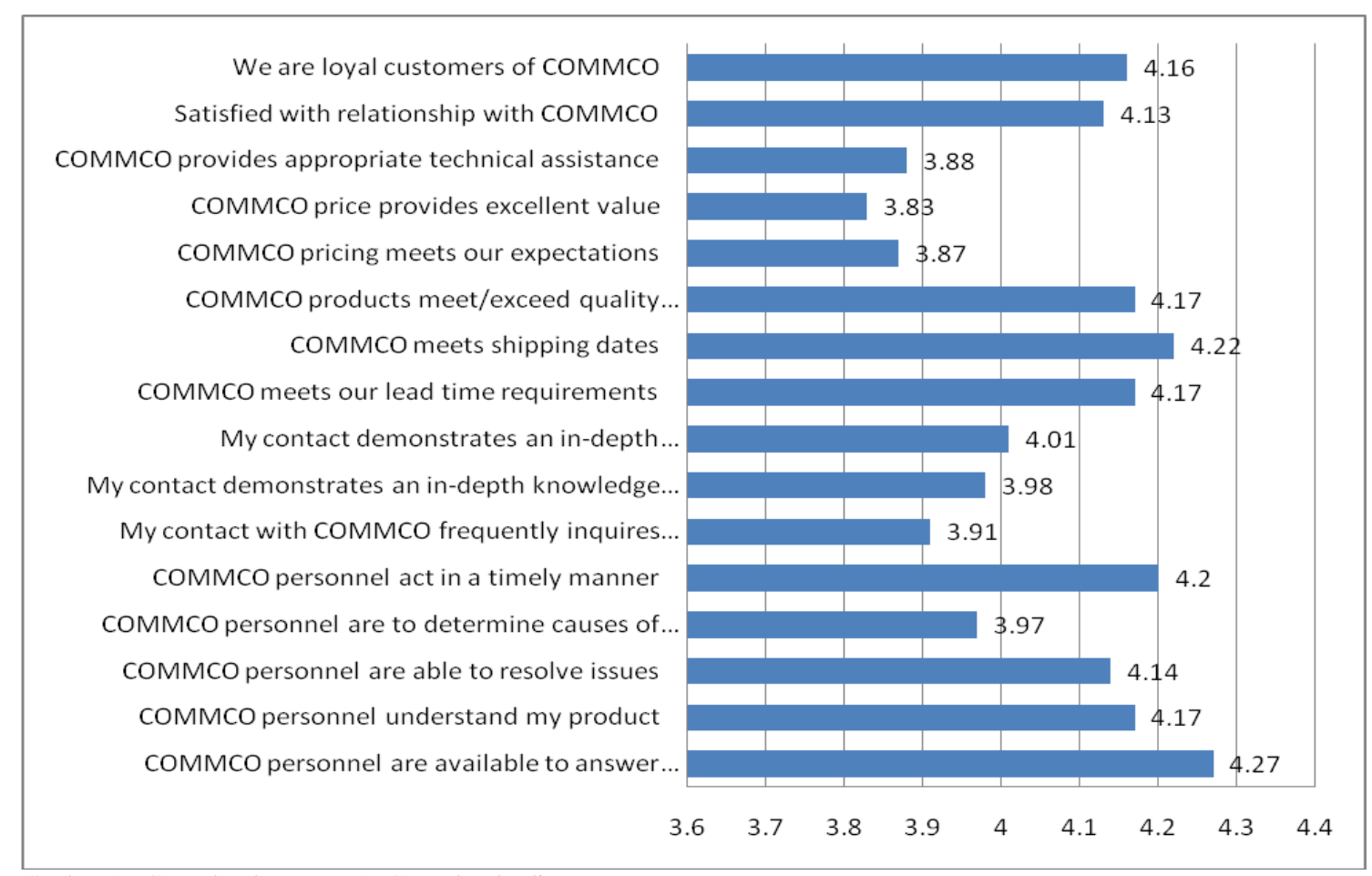

Scale: 5 - Completely agree, 1- Completely disagree

\section{COMMCO'S PERFORMANCE RELATIVE TO THEIR PRIMARY COMPETITOR}

Customers were asked to assess the performance of COMMCO compared to the performance of the firm the customer believed to be their closest competitor. Figure 3 presents the customers' average assessment of COMMCO's performance compared to their nearest competitor.

Figure 3: Performance Assessment of COMMCO Relative to Closest Competitor

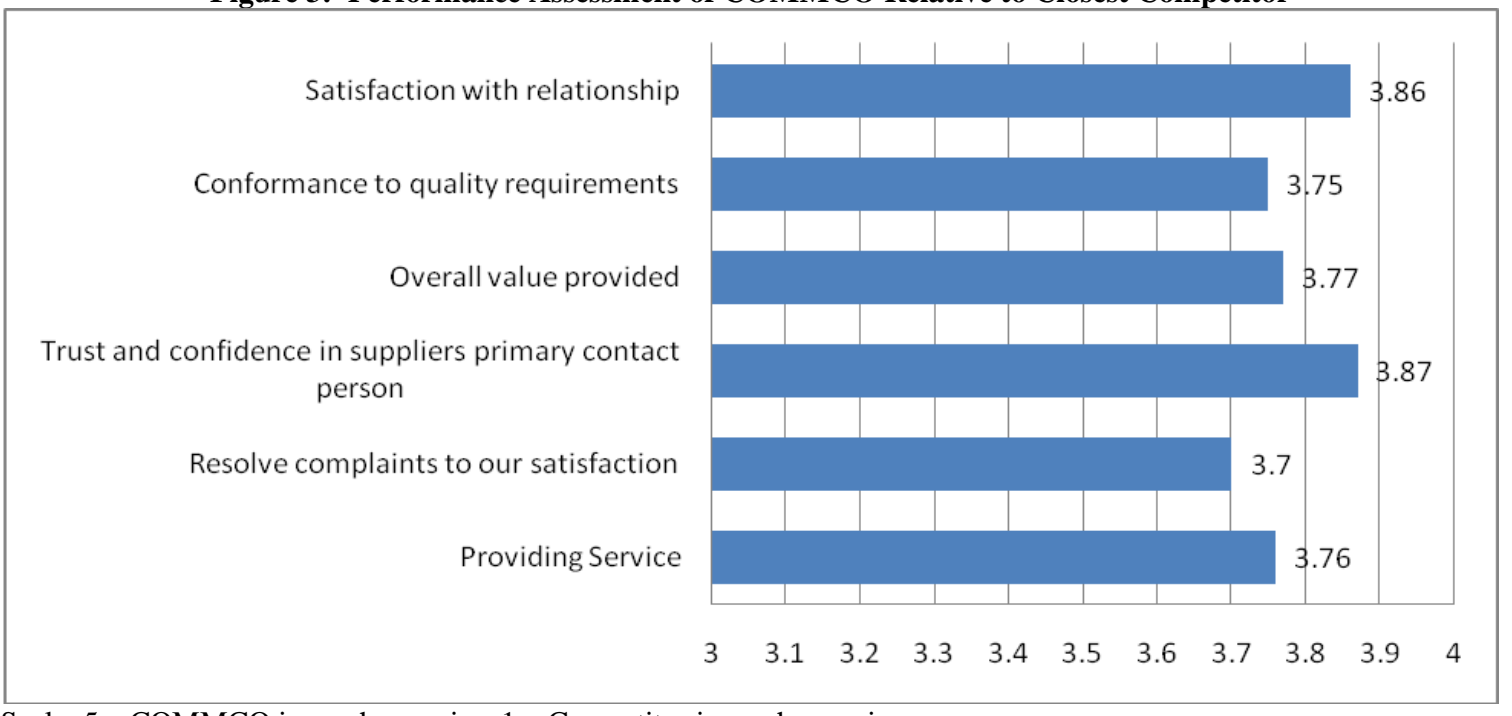

Scale: 5 - COMMCO is much superior; 1 - Competitor is much superior

\section{CUSTOMER SURVEY IMPLICATIONS}


The results of the survey provided Frank with much information concerning how customers assess the performance of suppliers and how well COMMCO performed. He was unsure, however, whether the information from the surveys would be viewed as validating their efforts to increase the organization's commitment to customer service as a differentiating factor to justify charging higher prices. He knew that he would have to provide the executives with substantial evidence on the success of the service program to maintain their support, especially in view of the pressure on the organization's profit margin.

\section{CASE QUESTIONS}

1. What does Figure 1 indicate about the criteria that customers use to evaluate their suppliers?

2. How do the results of this survey compare to past customer surveys COMMCO commissioned? Can they directly be compared?

3. Do the results of the factor analysis influence how Frank should interpret Figure 1?

4. What do figures 2 and 3 indicate about the performance of COMMCO?

5. What information contained in the survey results could Frank use to support his desire to continue the customer service initiatives?

6. Frank was concerned with the reaction of new customers in Asian and European markets. Can their responses be interpreted from these results?

7. Is there information that would make the Chief Executive reticent to extend the service commitment?

8. Does the information provided by the survey indicate areas COMMCO should be concerned about in the future?

\section{AUTHOR INFORMATION}

Charles J. Quigley Jr. is a Professor of Marketing at Bryant University and chairman of the Marketing Department. His research interests include strategic issues of service marketing, business-to-business marketing and profit/nonprofit marketing. Dr. Quigley has published previous research in numerous academic journals and actively consults with national and regional firms.

Frank G. Bingham, Jr. is a Professor of Marketing at Bryant University. Dr. Bingham's research interests include business-to-business marketing, profit/non-profit marketing, services marketing, and the marketing of higher education. He has published articles in numerous academic journals and is the author of several textbooks on business-to-business marketing.

\section{REFERENCES}

1. $\quad$ Engel, R. J. (2007) “Cultivate Supplier Relationships”, Inside Supply Management, Vol. 18 No. 11, pp. 2830 .

2. Knemeyer, A.M., Corsi, T. M. and Murphy, P.R. (2003) "Logistics Outsourcing Relationships: Customer Perspectives", Journal of Business Logistics, Vol. 24 No. 1, pp. 77-109.

3. Lambert, D. M., Knemeyer, A. M. and Gardner, J. T. (2004) "Supply Chain Partnerships: Model Validation and Implementation", Journal of Business Logistics, Vol. 25 No. 2, pp. 21- 40.

4. Moberg, C.R. and Speh, T.W. (2003) "Evaluating the Relationship Between Questionable Business Practices and the Strength of Supply Chain Relationships", Journal of Business Logistics, Vol. 24 No. 2, pp. 1-19.

5. Ruamsook, K., Russell, D., and Thomchick, E. (2007) "U.S. Sourcing from Low-Cost Countries: A Comparative Analysis of Supplier Performance", The Journal of Supply Chain Management, Vol. 43 No. 4, pp. 16-30.

6. Sanders, N. R., Locke, A., Moore, C. B., and Autry, C. W. (2007) “A Multidimensional Framework for Understanding Outsourcing Arrangements”, The Journal of Supply Chain Management, Vol. 43 N0. 4, pp. 2-15.

7. Van Pham, K-Q. (2006) "Strategic Offshoring from a Decomposed COO's Perspective: A Cross-Regional Study of Four Product Categories", Journal of American Academy of Business, Vol. 8 No. 2, pp. 59-68. 


\section{APPENDIX}

Table 1: Characteristics of Respondents

\begin{tabular}{llcc|ccc}
\hline \multicolumn{1}{c}{ CATEGORY } & \multicolumn{1}{c}{ Characteristic } & \multicolumn{2}{c}{ Current } & 2006 Study & $\begin{array}{c}\mathbf{2 0 0 4} \\
\text { Study }\end{array}$ & $\begin{array}{c}\mathbf{2 0 0 2} \\
\text { Study }\end{array}$ \\
\hline Respondents & & 146 & $100 \%$ & 141 & 113 & 82 \\
\hline Service Location & Non-USA & 17 & $13.0 \%$ & $12.0 \%$ & na & na \\
& USA & 127 & $87.0 \%$ & $88.0 \%$ & na & na \\
\hline Annual & \$500k & 30 & $21.4 \%$ & $19.0 \%$ & $39.0 \%$ & $51.0 \%$ \\
Purchases & $\$ 100 \mathrm{k}$ to $\$ 500 \mathrm{k}$ & 30 & $21.4 \%$ & $32.0 \%$ & $38.0 \%$ & $33.0 \%$ \\
& $<\$ 100 \mathrm{k}$ & 80 & $57.1 \%$ & $50.0 \%$ & $24.0 \%$ & $16.0 \%$ \\
\hline Bought from & $100 \%$ & 43 & $30.3 \%$ & $39.6 \%$ & $37.2 \%$ & $22.6 \%$ \\
Supplier & 50\% $>100 \%$ & 51 & $35.9 \%$ & $36.9 \%$ & $47.9 \%$ & $56.5 \%$ \\
& $<50 \%$ & 48 & $33.8 \%$ & $23.4 \%$ & $14.9 \%$ & $21.0 \%$ \\
\hline Area of & Purchasing & 88 & $60.3 \%$ & $68.2 \%$ & $62.6 \%$ & $51.2 \%$ \\
Responsibility & Operations & 28 & $19.2 \%$ & $19.4 \%$ & $23.8 \%$ & $13.4 \%$ \\
& Engineering & 12 & $8.2 \%$ & $9.3 \%$ & $19.8 \%$ & $24.2 \%$ \\
& Quality Assurance & 2 & $1.4 \%$ & na & na & na \\
& Other & 10 & $6.7 \%$ & $1.6 \%$ & $15.8 \%$ & $11.0 \%$ \\
\hline Supplier & Sales Account Manager** & 68 & $46.6 \%$ & $17.1 \%$ & $12.7 \%$ & $52.4 \%$ \\
Contact & Customer Service Rep & 66 & $45.2 \% 7$. & $67.4 \%$ & $54.9 \%$ & $41.5 \%$ \\
& Operations Professional & 3 & $0 \%$ & $1.6 \%$ & $8.0 \%$ & $6.1 \%$ \\
& R\&D Professional & 2 & $2.1 \%$ & $2.3 \%$ & $4.4 \%$ & na \\
& Other & 3 & $2.7 \%$ & $11.6 \%$ & na & na \\
\hline
\end{tabular}

* - Two locations identified (the other location was USA); ** - category identified as Sales Engineer in 2005/2003/2001 studies; na. - Not available or not measured

Table 2: Importance of Evaluation Criteria: Comparison to Prior Studies

\begin{tabular}{|c|c|c|c|c|c|}
\hline $\begin{array}{c}\text { Rank } \\
\text { Current }\end{array}$ & Criteria & Current & 2006 & 2004 & 2002 \\
\hline 1 & Delivery of Product as Agreed & 9.48 & $9.36(1)$ & $9.63(1)$ & $9.59(1)$ \\
\hline 2 & Reliability of Supply & 9.18 & $9.22(2)$ & $9.53(2)$ & $9.55(2)$ \\
\hline 3 & Quality of Products & 9.17 & na & na & na \\
\hline 4 & Price & 8.70 & $9.05(3)$ & $9.24(3)$ & $8.94(3)$ \\
\hline 5 & Overall Value Provided & 8.34 & na & na & na \\
\hline 6 & Complaint Resolution & 8.25 & $8.84(4)$ & $9.11(4)$ & $8.94(4)$ \\
\hline 7 & Overall Relationship & 8.20 & $8.36(7)$ & $8.81(5)$ & $8.61(5)$ \\
\hline 8 & Relationship with Supplier's Rep & 8.02 & $7.94(9)$ & $8.46(8)$ & $8.33(6)$ \\
\hline 9 & Financial Stability & 7.94 & $8.41(6)$ & $8.64(6)$ & $8.22(8)$ \\
\hline 10 & Knowledge of Industry & 7.80 & $8.00(8)$ & $8.39(9)$ & $7.90(9)$ \\
\hline 11 & Exchange Information & 7.64 & na & na & na \\
\hline 12 & Co-development New Products & 7.32 & $6.13(13)$ & $7.61(10)$ & $7.18(12)$ \\
\hline 13 & Unique Features & 7.18 & $6.68(11)$ & $7.48(11)$ & $7.41(10)$ \\
\hline 14 & Depth of Line & 6.68 & $7.54(10)$ & $7.42(12)$ & $7.27(11)$ \\
\hline 15 & Electronically Share Information & 6.64 & na & na & na \\
\hline 16 & ISO Certification & 6.50 & na & na & na \\
\hline \multirow[t]{2}{*}{17} & Number of New Products & 5.94 & $6.57(12)$ & $6.37(13)$ & $6.45(13)$ \\
\hline & Ease of Ordering & & $8.65(5)$ & $8.50(7)$ & $8.28(7)$ \\
\hline
\end{tabular}

* Scale 1 - Not important, 10 - Extremely important

na - Not available or not measured 


\section{TEACHING NOTES}

The market that this firm competes in can be described as a mature oligopoly, with a product perceived as a commodity. This is indicated by the increasing importance of price relative to product related criteria, including product quality. Firms that are not low cost providers attempt to differentiate their offering by providing additional services. The findings of this survey illustrate that customers demand that vendors deliver quality products as specified when and where needed. These appear to be minimal criteria that vendors are expected to meet. This indicates that organizations that desire to develop and maintain ongoing relationships with their customers must first provide the value they have promised, deliver when and where promised, and be consistent. These are minimal criteria required to maintain a strong relationship with customers. The survey results also indicate that although price is still considered an important factor in maintaining relationships, it takes a back seat to providing a quality product offering when and where promised.

Figure 1 and Table 2 list criteria ranked from most important to least important based on mean scores for all respondents. Table 2 also includes responses, with ranking in parentheses, from the prior studies. The most important criteria, rated 9 or higher on a 10 point importance scale by the respondents were:

- $\quad$ Filling Order (Delivery of Products as Agreed) (9.5)

- Reliability of Supply (9.2)

- $\quad$ Quality of Products (9.2)

Important criteria, rated between 8 and 9 on the importance scale, are:

- $\quad$ Price (8.7)

- $\quad$ Overall value provided (8.3)

- $\quad$ Complaint Resolution (8.3)

- $\quad$ Overall Relationship (8.2)

- $\quad$ Relationship with Supplier's Representative (8.0) criteria are:

Five criteria were evaluated as being relatively less important, with mean ratings of between 7 and 8 . These

- $\quad$ Financial Stability (7.9)

- $\quad$ Knowledge of the Industry (7.8)

- $\quad$ Ability to Rapidly Exchange Information with Supplier (7.6)

- $\quad$ Co-development of New Products (7.3)

- $\quad$ Unique Product Features (7.2)

Four criteria were considered least important in evaluating the performance of suppliers:

- $\quad$ Depth and Breadth of Supplier's Product Line (6.7)

- $\quad$ Electronically Share Information with Supplier (6.6)

- $\quad$ ISO Certification (6.5)

- $\quad$ Number of New Products (5.9)

These findings are consistent with prior studies and indicate that the primary factors customers used to evaluate the performance of their suppliers have remained stable. Reliable, timely, and consistent delivery of products were the most important factors customers used. Price was important, but not as important as delivery factors. New technology that has allowed firms to rapidly share information, especially electronically, was not considered important by the organization's customers. ISO Certification was also not considered important in evaluating performance.

Factor analysis is a method of analysis that allows decision makers to determine if the measures used 
(questions asked) represent something else. Do multiple questions measure the same underlying factor? The factor analysis conducted by the research firm and reported to COMMCO's management suggests that there are several underlying dimensions that their customers are using to evaluate their suppliers, including COMMCO.

The first dimension, defined as "Supplier's Product Offering", accounts for over one third (34\%) of the variation among all seventeen criteria. "Excellence of Supplier's Service" accounts for $11 \%$ of total variation in responses. Three other dimensions add only $19 \%$ to explained variation. This suggests that the "Supplier's Product Offering" dimension and "Excellence of Supplier's Service" dimension are the two critical dimensions underlying customers' evaluation of their suppliers.

To differentiate the organization from competitors will require the firm to understand the specific needs of the customer and the attributes they seek. For some customers, product related factors, including Unique Product Features, Abundance of New Products, and Depth of their Product Line, serve to separate suppliers. For others, rapid response of their vendor's representative to their concerns may be a differentiating factor.

Frank can point to the findings contained in Figure 3 to support his contention that his service initiatives are effective. Figure 3 indicates that customers are pleased with the relationship they have developed with COMMCO and the personal relationship they have with their COMMCO representative. This should be apparent from the results reported in figure 1 and figure 2. Figure 1 indicates that for factors considered critical, Filling Orders on Time, Reliability of Supply, and Quality of Products, COMMCO's performance far exceeds that of their closest competitor.

Price competition from the Asian market was of concern to Frank. The results reported to him are not broken down by the geographic location of their customers. The limited number of surveys returned from customers in the Asian and European markets makes it difficult to draw meaningful insights by grouping the customers into geographic areas. It may be helpful to determine if the importance of measures, especially price and service related criteria, differ by geographic location.

Although the results of the survey demonstrate that customers are pleased with the performance of COMMCO, there is information contained in Table 1 that may be of concern to both Frank and the CEO and which may portent future conditions. The percentage of customers that reported purchasing more than $\$ 100,000$ but less than $\$ 500,000$ from COMMCO dropped from $32 \%$ in 2006 to $21.4 \%$. The share of customers reporting purchasing less than $\$ 100,000$ was $57.1 \%$.compared to $50 \%$ in the 2006 study and $24 \%$ in the 2003 study. The reasons for this decrease in order quantity per customer should be investigated further.

COMMCO's share of their customers' business declined from the shares reported in 2006. Slightly more than thirty percent $(30.3 \%$ ) indicated they purchased $100 \%$ of their product from COMMCO. This was down from nearly forty percent $(39.6 \%)$ in the previous study. The share of customers that reported purchasing less than $100 \%$ but more than $50 \%$ of their product from COMMCO declined slightly to $35.9 \%$ in the current study from $36.9 \%$ in the prior study. The percent that reported purchasing less than $50 \%$ of product from COMMCO increased from $23.4 \%$ in 2006 to $33.8 \%$.

\section{NOTES}

